Animal Health Research Institute, Assiut Regional Laboratry.

\title{
INCIDENCE OF AEROMONAS HYDROPHILA IN FRESH WATER FISH (TILAPIA NILOTICUS) AND READY TO EAT FRIED FISH IN ASSIUT CITY
}

(With 4 Tables)

By

H.H. ESSA; A.M. MANAA and N.H. MAKAR

(Received at 14/10/2009)

مدي تواجد ميكروب الأيروموناس هيدروفيلا في الأسماك الطازجة

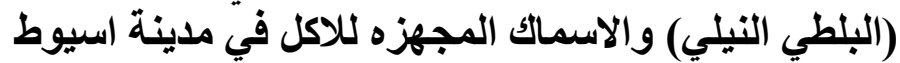

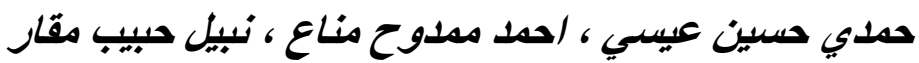

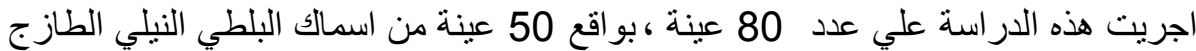

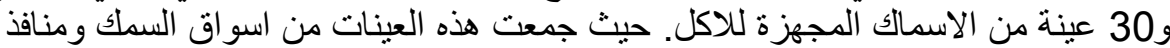

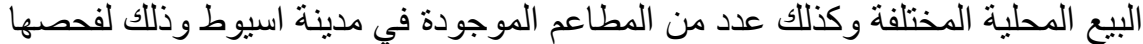

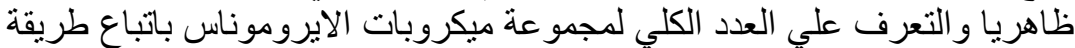

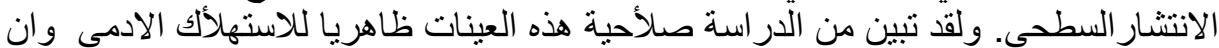

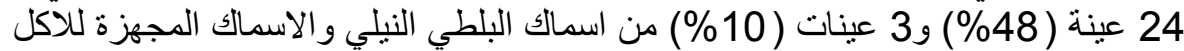

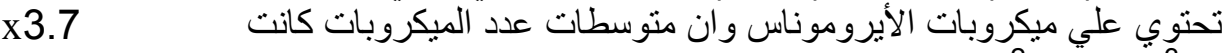

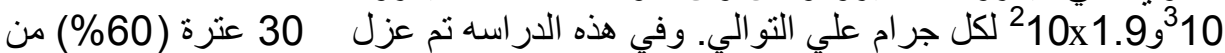

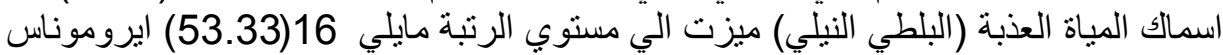

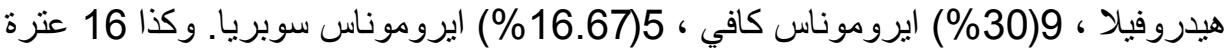

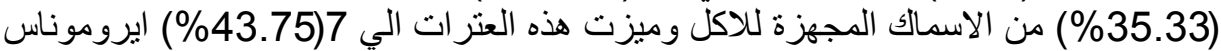

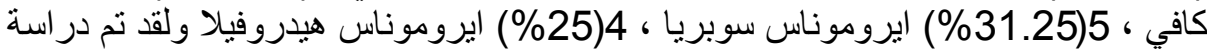

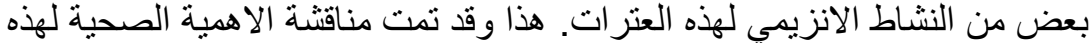

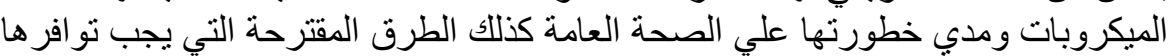

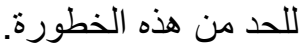

\section{SUMMARY}

This study was carried on 80 random samples 50 of fresh water fish (Tilapia niloticus) and 30 samples of ready to eat fried fish these samples were obtained from different shops; represented different localities of different sanitation levels of ९्Assiut city. All samples were examined for the presence of Aeromonas hydrophila group; using enrichment 
procedure and surface spread plate technique. The results obtained pointed out that $48 \%$ and $10 \%$ of the examined Tilapia niloticus fish and ready to eat fried fish samples were positive for the presence of Aeromonas hydrophlia organism with an average counts of $3.7 \times 10^{3}$ and $1.9 \times 10^{2} / \mathrm{g}$ fish respectively. In this study 30(60\%) Aeromonas strains were isolated from fresh water fish (Tilapia niloticus) and were characterized according to species level as follow; 16 (53.33\%) Aeromonas hydrophlia; 9(30\%) Aeromonas caviae and 5(16.67\%) Aeromonas sabria. On the other hand $16(53.33 \%)$ strains were isolated from ready to eat fried fish and were characterized according to species level as follows: 7 (43.75\%) Aeromonas caviae, 5 (31.25\%) Aeromonas sabria and 4 (25\%) Aeromonas hydrophlia. All strains were examined for their ability to produce haemolysin as a virulence factor. The hygienic and public health importance as well as some recommended measures for improving the quality of such products were discussed.

Key words: Fish, fresh water fish, fried fish, Aeromonas spp.

\section{INTRODUCTION}

Aeromonas hydrophila (A. hydrophila), a gram negative bacteria, is widely distributed in aquatic environment (Nakano, et al., 1990; Fiorentini, et al., 1998; Legnani, et al., 1998). A. hydrophila has received a particular attention because of its association with infections in a wide variety of hosts including, human, reptiles fish and invertebrates (Kodjo et al., 1997; Pearson et al., 2000; Roux et al., 2000). More ever the bacterium is considered as one of the newly emerging water and food borne pathogens (Merino et al., 1995; Gugnani, 1999). In fish A. hydrophila typically causes an exploded haemorrhagic septicemia and has been implicated in different outbreaks associated with heavy losies (Qian et al., 1995; Son et al., 1997).

Species of Aeromonas are short, gram negative, faculatively anaerobic, non spore forming, motile bacilli with a single flagellum, and can ferment glucose with or without the production of gas (Andrade, et al., 2006). The most important three motile species associated with human illness are Aeromonas hydrophila, A. caviae and A. sobria (Brooks et al., 1995). Isolation of these bacteria (Aeromonas hydrophila group), have been reported from a variety of food including fishes (Adithepchaikram et al., 2008)

In addition to gastro_enteritis Aeromonas hydrophila group infects human causing infections such as septicaemia, acute diarrhea of 
short duration, urinary tract infection and ear infection (Koneman et al., 1994). The Aeromonas hydrophila group produces a number of potential virulence factors, including enterotoxins, haemolysins, cytotoxins and proteases (Ljungh and Wadstrom, 1983). The Aeromonas microorganisms are normal inhabitant of the intestinal tract of O.niloticus (Akelah, 1978). However, Aeromonas hydrophila, Aeromonas sobria, and Aeromonas caviae has been implicated in some cases of diarrheal disease. Aeromonas sobria and Aeromonas hydrophila are the primary enteropathognic species, however Aeromonas caviae has been implicated in some cases of diarrheal disease (Topic et al., 2000).

In addition, Beta haemolytic strains of Aeromonas are assigned to Aeromonas hydrophlia and Aeromonas sobria, although haemolytic strains of Aeromonas caviae have been also found (Deodhar et al., 1991). Burke et al. (1981) mentioned that the haemolytic activity is strongly associated with enterotoxin production in members of Aeromonas genus.

Rugulska, A., et al. (1994) reported that the haemolytic activity of Aeromonas hydrophila and Aeromonas sobria act as marker of pathogenicity therefore, the initial purpose of this study was to determine the occurrence and level of Aeromonas organisms in fresh water fish (Tilapia niloticus) and ready to eat fried fish in Assiut city markets.

\section{MATERIALS and METHODS}

\section{1 - Collection of samples:-}

Atotal of 80 random samples of fresh water fish (Tilapia niloticus) (50 samples) and ready to eat fried fish (30 samples) were collected from fish markets, shops and restaurants of varied sanitary levels at Assuit city.

Each sample was put in a sterile plastic bag. The collected samples were transferred directly to the laboratory under aseptic conditions without any delay where they were organoleptically and bacteriologicaly examined.

\section{2 - Organoleptic examination:-}

Ready to eat fried fish were evaluated for their palatability and odour of the flesh, while the fresh water fish were examined for their skin condition, consistency, colour, scales, eyes and gills according to Anon, (1985). 


\section{3 - Bacteriological examination:-}

The samples were analyzed by using enrichment method as recommended by Okrend et al. (1987), where 25gram sample were aseptically transferred to $225 \mathrm{ml}$ of trypticase soy broth containing 10 $\mathrm{mg}$ ampicillin / $\mathrm{ml}$ and blended for $2 \mathrm{~min}$. The prepared samples were serially diluted up to $10^{6}$ in butterfieds phosphate dilutent, and the count was carried out on the aforementioned dilutions as recommended by Palumbo et al. (1985), using MacConky manitol ampicillin agar. The number of colonies which showed red colour in countable plates was enumerated as Aeromonas organisms.

\section{a- Enrichment procedure:}

This was done according to the technique adopted by Palumbo et al. (1989).

\section{b- Isolation and identification techniques:-}

The technique adopted was that used by Okrend et al. (1987), Ahmed et al. (1991), and Koneman et al. (1994).

\section{c- Determination of the haemolytic activity of the isolated strains:}

It was carried out using 5\% sheep blood agar as recommended by Rogulska et al. (1994).

\section{RESULTS}

Table 1: Organoleptic examination of fresh and fried fish samples.

\begin{tabular}{|c|c|c|c|}
\hline \multirow{2}{*}{$\begin{array}{c}\text { Type of } \\
\text { samples }\end{array}$} & \multirow{2}{*}{$\begin{array}{c}\text { No. of } \\
\text { Samples }\end{array}$} & \multicolumn{2}{|c|}{ Organoleptic examination } \\
\cline { 3 - 4 } & 50 & Fresh samples & Stale samples \\
\hline $\begin{array}{c}\text { Fresh water fish } \\
\text { (Tilapia niloticus) }\end{array}$ & 50 & $\begin{array}{c}50 \\
(100 \%)\end{array}$ \\
\hline $\begin{array}{c}\text { Ready to eat } \\
\text { fried fish }\end{array}$ & 30 & $\begin{array}{c}30 \\
(100 \%)\end{array}$ & $\begin{array}{c}0 \\
(0.0 \%)\end{array}$ \\
\hline
\end{tabular}

Table 2: Statistical analytical results of Aeromonas species count/g examined samples.

\begin{tabular}{|c|c|c|c|c|c|c|c|}
\hline & \multirow{2}{*}{$\begin{array}{c}\text { No. of } \\
\text { Type of } \\
\text { samples }\end{array}$} & $\begin{array}{c}\text { Examined } \\
\text { samples }\end{array}$ & $\begin{array}{c}\text { Positive } \\
\text { samples }\end{array}$ & \multicolumn{5}{|c|}{ Count/g of Fish } \\
\cline { 3 - 8 } & No & $\%$ & Min & Max & Mean & SE \\
\hline $\begin{array}{l}\text { Fresh } \\
\text { water fish }\end{array}$ & 50 & 24 & 48 & $1.8 \times 10^{2}$ & $6.4 \times 10^{5}$ & $3.7 \times 10^{3} / \mathrm{g}$ & $2.3 \times 10^{3}$ \\
\hline $\begin{array}{l}\text { Ready-to- } \\
\text { eat fried } \\
\text { fish }\end{array}$ & 30 & 3 & 10 & $2 \times 10$ & $3.1 \times 10^{3}$ & $1.9 \times 10^{2} / \mathrm{g}$ & $1.2 \times 10^{2}$ \\
\hline
\end{tabular}


Table 3: Incidence of Aeromonas species isolated from the examined samples.

\begin{tabular}{|c|c|c|c|c|c|c|c|}
\hline \multirow{2}{*}{$\begin{array}{c}\text { Type of } \\
\text { Samples }\end{array}$} & $\begin{array}{c}\text { No.of } \\
\text { Isolated } \\
\text { strains }\end{array}$ & \multicolumn{2}{|c|}{$\begin{array}{c}\text { Aeromonas } \\
\text { hydrophila }\end{array}$} & \multicolumn{2}{c|}{$\begin{array}{c}\text { Aeromonas } \\
\text { caviae }\end{array}$} & \multicolumn{2}{|c|}{$\begin{array}{c}\text { Aeromonas } \\
\text { sobria }\end{array}$} \\
\cline { 3 - 8 } & NO. & $\%$ & NO. & $\%$ & NO. & $\%$ \\
\hline $\begin{array}{c}\text { Fresh water fish } \\
\text { (Tilapia niloticus). }\end{array}$ & $\begin{array}{c}30 \\
(60 \%)\end{array}$ & 16 & 53.33 & 9 & 30 & 5 & 16.76 \\
\hline $\begin{array}{c}\text { Ready-to-eat fried } \\
\text { fish }\end{array}$ & $\begin{array}{c}16 \\
(53.33 \%)\end{array}$ & 4 & 25 & 7 & 43.75 & 5 & 31.25 \\
\hline
\end{tabular}

Table 4: Detection of haemolysin activity of Aeromonas species isolated from fresh water fish (Tilapia niloticus) and ready-to-eat fried fish.

\begin{tabular}{|l|c|c|c|c|c|c|}
\hline \multirow{2}{*}{$\begin{array}{c}\text { Aeromonas } \\
\text { Species }\end{array}$} & \multicolumn{6}{|c|}{ Haemolysin activity } \\
\cline { 2 - 7 } & \multicolumn{4}{|c|}{ Fresh water fish } & \multicolumn{2}{c|}{ Ready -to-eat fried fish } \\
\cline { 2 - 7 } & $\begin{array}{c}\text { No. } \\
\text { tested }\end{array}$ & $\begin{array}{c}\text { No. } \\
\text { positive }\end{array}$ & $\%$.positive & $\begin{array}{c}\text { No. } \\
\text { tested }\end{array}$ & $\begin{array}{c}\text { No. } \\
\text { positive }\end{array}$ & $\%$.positive \\
\hline A. hydrophila & 16 & 11 & 68.75 & 4 & 1 & 25 \\
\hline A. caviae & 9 & 1 & 11 & 7 & 3 & 42.86 \\
\hline A. sorbia & 5 & 2 & 40 & 5 & 2 & 40 \\
\hline
\end{tabular}

\section{DISCUSSION}

This study was conducted to investigate the presence of Aeromonas species in fresh water fish (Tilapia niloticus) and ready to eat fried fish.

Although the organoleptic examination showed no abnormalities and all the examined samples were fresh and sound, yet Aeromonas organisms were recovered from fresh water fish (Tilapia niloticus) and ready to eat fried fish (Table 1), therefore bacteriological examination must be associated with organoleptic examination to give the accurate judgment.

From (Table 2), it is apparent that $24(48 \%)$ and 3(10\%) of fresh water fish (Tilapia niloticus) and ready to eat fried fish contained 
Aeromonas species with an average count of $3.7 \times 10^{3}$ and $1.9 \times 10^{2} / \mathrm{gm}$ respectively.

The obtained incidence are somewhat higher than that reported by Gobat and Jemmi (1992); Abdel. EL-Daym (1999) and Bastawrows and Mohamed (1999).

It was observed that the fresh water fish showed higher incidence and count than that from ready to eat fried fish as Aeromonas microorganisms are normal inhabitant of the intestinal tract of Tilapia niloticus (Akelah, 1978).

From Table (3), 30(60\%) strains of Aeromonas organisms were isolated from the examined fresh water fish (Tilapia niloticus). Aeromonas hydrophlia was the most common species isolated (53.33\%) followed by Aeromonas caviae (30\%) strains and Aeromonas sobria $(16.67 \%)$. On the other hand $16(53.33 \%)$ strains were recovered from ready to eat fried fish where Aeromonas caviae was the most common species isolated (43.75\%) followed by Aeromonas sobria $(31.25 \%)$ and Aeromonas hydrophila (25\%).

It is evident from the data presented in Table (4) that 11 (68.75\%) of 16 Aeromonas hydrophila strains, 2(40\%) of 5 Aeromonas sobria strains and only one (11\%) of 9 Aeramonas caviae strains, while $3(42.86 \%)$ of 7 Aeramonas caviae strains, 2 (40\%) of 5 Aeromonas sobria and only one (25\%) of 4 Aeromonas hydrophila strains from fresh water fish and ready to eat fried fish had the ability to produce haemolysin respectively.

Abyta et al. (1994) identified Aeromonas hydrophlila and Aeromonas sobria as the primary enterophogenic species, however Aeromonas caviae has been implicated in some cases of diarrheal disease (Topic et al., 2000).

In addition, Beta haemolytic strains of Aeromonas are assigned to Aeromonas hydrophila and Aeromonas sobria, although haemolytic strains of Aeromonas caviae have been also found (Deodhar et al., 1991).

Varnam, and Evans, (1991) reported that a number of phenotypic characters have been proposed as a markers of enteropathogenicity of Aeromonas species and they added that the most important of these markers was haemolysin production.

The present results disagree, with those reported by Okrend et al. (1987); Palumbo et al. (1989) and Freitas et al. (1992) since these authors pointed out that haemolysin was detected in $100 \%$ of Aeromonas hydrophila strains recovered from some varities of food. 
On the other hand, Bastawrows and Mohammed (1999) found that more of the 12 strains of Aeromonas caviae recovered from fresh water fishes lysed the sheep erythrocytes.

In conclusion, the information given by the achieved results revealed that Aeromonas species existed in the examined fishes either fresh water fish or ready to eat fried fish and therefore these foods may play a significant role in the epidemiology of gastroenteritis, therefore, strict hygienic measures, good food handling practice at home and finally thoroughly and properly clean and sanitary equipments and contact surfaces should be recommended to avoid contamination with Aeromonas organisms.

\section{ACKNOWLEDGMENT}

I wish to express sincere thanks to Prof. Dr A. EL-Tamawy Professor of bacteriology, Faculty of Medicine, Assiut University for his help in Aeromonas serotyping.

\section{REFERENCES}

Abd-El-Daym, W.F.A. (1999): Microbiological aspects of smoked fishes at retail outlets. Master D.Thesis, Vet. Med. Sci. (Meat Hygiene) Zagazig Univ.

Abyta, C.; Palumbo, S.A. and Stelma, G.N. (1994): Aeromonas hydrophila group, Ch.I in Y.H. Hui; J.r.Gorham, K.D. Murrell and D.O.Cliver (ed), foodborne disease handbook. Diseases caused by bacteria. Marcel Dekker, Inc., New York.

Adithepchaikarm, P.; Parichat, P. and Pongsak, R. (2008): Potential of Psidium gaajava supplemented fish diets in controlling Aeromonas hydrophila infection in Tilapia (Oreochromis niloticus). J. of Bioscience and Bioengineering. 106, 5: 424- 230

Ahmed, M.Sh.; Zaitoun, A.M. and Ali, H.S. (1991): Motile Aeromonas septicaemia (MAS) in Mormyrus Kannume at Assiut Governorate. Assiut Vet. Med. J., 25: 145-150.

Akelah, M.A. (1978): Some studies on intestinal flora of the genus Tilapia in the Manzalah fish farm. M.V. Sc.Thesis, Fac. Vet. Med. Zagazig Univ.

Andrade, J.M.; Cairrao, F. and Arraiano, C.M. (2006): RNase R affects gene exp. regulation of ompA. 1. Mol. Microbial. 60: 219-228. (PubMed). 
Anon (1985): Avoidness of losses in preserved fishes. Food and Agriculture Organization of United Nations, Rome.Technical report series No. 219: 16-100.

Bastawrows, A.F. and Mohamed, A.A. (1999): Some microbiological investigations on Aeromonas hydrophila group in Oreochromis

Brooks, G.F.; Butel, J.S.; Nicholas Ornston, L.; Jawetz, E.; Melinick, J.L. and Adellberg, E.A. (1995): Medical Microbiology, $20^{\text {th }}$ ed. Prentice-Hall International Inc. pp. 226-227.

Burke, V.; Robinson, J.; Atkinson, H.M.; Dibley, M.; Berry, R.J. and Gracey, M. (1981): Exotoxins of Aeromonas hydrophila. Australian Journal of Exprimental Biological and Medical Sciences. 59: 753-761.

Deodehar, L.P. Saraswathi, K. and Varudkar, V. (1991): Aeromonas spp. and their association with human diarrheal disease. J. Clin. Microbiol., 29: 853-856.

Freitas, A.C.; Nunes, M.P.; Milhomemn, A.M. and Ricciardi, I.D. (1992): Occurrence of Aeromonas species in pasteurized milk and white cheese in Reo de Janeiro, Brazil. J. Food. Prot., 56: 62-65.

Fiorentini, C.; Barbieri, E.; Falzano, L.; Matarrese, P.; Baffpne, W.; Pianetti, A.; Katouli, M.; Kiuhn, I.; Miolby, RR.; Bruscolini, F.; Casiere, A. and Donelli, G. (1998): Occurrence, diversity and pathogenicity of mesophilic Aeromonas in estuarine waters of Italian coast of the Adriatic sea Appl. Microbiol. 85(3): 501-511.

Gobat, P.F. and Jemmi, F. (1992): Occurrence of Aeromonas spp. in poultry and fish products. Proceeding of $3^{\text {rd }}$ World Congress, Food borne Infection and Intoxication.Berlin, pp. 1100.

Gugnani, H.C. (1999): Some emerging food and water borne pathogens. Commun. Dis. 31(2): 65-72.

Kodjo, A.; Haond, F. and Richard, Y. (1997): Molecular and phenotypic of Aeromonas isolated from snails (Helix aspersa) affected with a new summer disease. Zentraralbl. Veterinarmed. (B), 44(4): 245-252.

Koneman, E.W.; Allen, S.D.; Janda, W.M.; Schreckenberger, P.C. and Winn, W.C. Jr. (1994): Introduction to Diagnostic Microbiology J.B. Lippinctt Company pp. 117-123. 
Legnani, P.; Leoni, E.; Soppelsa, F. and Burigo, R. (1998): The occurrence of Aeromonas species in drinking water supplies of an area of the Dolomite Mountains, Italy. Appl. Microbiol. 85(2): 271-276.

Ljungh, A. and Wadstorm, T. (1983): Toxins of Vibrio Parahaemolyticus and Aeromonoas hydrophila. J. Toxicol. Toxin Rev. 1: 257-259.

Merino, S.; Rubires, X.; Knochel, S. and Tomas, J.M. (1995): Emerging pathogens: Aeromonas spp.J. Food. Microbiol 28(2):157-168.

Nakano, H.; Kameyama, T.; Venkateswaran, K.; Kawakami, H. and Hashimoto, H. (1990): Distribution and characterization of hemolytic, and enteropathogenic motile Aeromonas in aquatic environment.Microbiol. Immunol. 34: 447-485.

Okrend, J.G.A.; Rose, B.B. and Bennett, B. (1987): Incidence and toxigenicity of Aeromonas species in retail poultry, beef and pork. J. Food Port., 50: 509-513.

Palumbo, S.A.; Bencivengo, M.M.; Corral, F.D.; Williams, A.C. and Buchanan, R.L. (1989): Characterization of Aeromonas hydrophila group isolated from retail food of animal origin. J. Clin. Microbiol., 27: 854-829.

Palumbo, S.A.; Maxino, F; Williams, A.C.; Buchanan, R.L. and Thayar, D.W. (1985): Strach-Ampicillin Agar for the quantitative detection of Aeromonas hydrophila Appl. Environ. Microbiol. 50(4): 1027-1030.

Pearson, M.D.; Hirono, I.; Aoki, T.; Miranda, R.; Inglis, V. (2000): Virulence properties of motile Aeromonas isolated from farmed frogs Rana Tigerina and R.rugulosa. Dis. Aquant. Organ. 40(3): 185-193.

Qian, D.; Chen, Y.; Shen, J. and Shen, Z. (1995): Serogroups, virulence and hymolytic activity of Aeromonas hydrophila which caused fish bacterial septicemia. Sheng. Wu. Hsueh. Pao. 35(6): 460-464.

Rogulska, A.; Antychowicz, J. and Zelanzy, J. (1994): Haymolytic and proteolytic activity of Aeromonas hydrophila and Aeromonas sobria as markers of pathogenicity for carp (Cyrians carpiol). Medycyna Weterynaryina 50 (2): 55-58.

Roux, M.; Coppere, B.; Desmurs, H. and Ninet, J. (2000): Septic arthritis caused by Aeromonas hydrophila (letter). Med. 29(15): 839. 
Son, R.; Rusul, G.; Sahilah, A.M.; Zainuri, A.; Raha, A.R. and Salmah, I. (1997): Antibiotic resistance and plasmid profile of Aeromonas hydrophila isolates from cultured fish, (Tilapia mossambica). Appl. Microbiol. 24(6): 479-482.

Topic, L.N.; Teskeredgic, E.I.; Ctrunjak, P. and Co7-Rakovac, (2000): Aeromonas hydrophila isolated from wild fresh water fish in Croatia-V. Research Communications, 24, 371-377.

Varnam, A.H. and Evans, M.G. (1991): Aeromonas. In foodborne pathogens. Wolfe Publishing Ltd. London. 